\title{
AIR-SPARGING REMEDIATION: A STUDY ON HETEROGENEITY AND AIR MOBILITY REDUCTION
}

${ }^{1}$ S. S. Di Julio and ${ }^{2}$ A. S. Drucker

${ }^{1}$ Mechanical Engineering Department, California State University, Northridge, 18111

Nordhoff St., Northridge, CA 91330-8348; Phone: (818)677-2496; Fax: (818)677-7062;

sdijulio@ecs.csun.edu.

${ }^{2}$ NFESC,US Navy; Phone: (805)982-4847; adrucke@nfesc.navy.mil.

\begin{abstract}
Contaminated groundwater is a widespread problem often requiring innovative technologies to remediate. In this study, physical models of the air-sparging process are developed, and contaminant recoveries are compared with predictions from a mathematical model. Initial tests used a very fine, porous media (a glass bead-packed column) to represent relatively homogeneous soil samples. Subsequent testing employed budded core samples taken from an actual site to represent more realistic, heterogeneous samples. 1,1,1 trichloroethane (TCA) was used as the dissolved contaminant to represent benzene, toluene, ethyl benzene, and xylene (BTEX), considered to be gasoline contamination in water. The results obtained, however, can be applied to any nonaqueous-phase liquid (NAPL) dissolved phase. A technique based on foam injection is proposed and is demonstrated to reduce air mobility. This reduction in air mobility has the potential to improve contaminant removal due to increased contact area, and contact time between the air and contaminant. Laboratory results are compared with predictions from an advection - diffusion, air-sparge numerical simulation model. Sensitivity analysis of the numerical model provides the range of key parameters used to evaluate air sparging. Eventual scaleup of the model to an actual site can be justified by the favorable results presented in this paper.
\end{abstract}

Key words: remediation, air sparging, NAPL, foaming surfactant

\section{BACKGROUND}

The efficiency of air sparging as a groundwater remediation process depends, to a large extent, on contact time and contact area of air with contaminated water. A number of investigators have conducted laboratory or field studies or numerical simulation in order to better understand air distribution, and a few have conducted studies to measure the removal rate of contaminants from groundwater. The majority of these studies have chosen homogeneous porous media, either 2D/3D glass beads, sand packs, or core samples for laboratory studies, and/or homogeneous strata for field studies. Ji et al. (1993), Ahfeld et al. (1994), and Clayton (1998) have demonstrated the tendency of air channels to develop in response to heterogeneity, at both pore scale and larger scale, in coarse to fine homogeneous sand. The transition from pore-scale viscous fingering to macroscopic capillary air channeling is estimated by Clayton (1998) to occur at an air-entry pressure of about 15 to $20 \mathrm{~cm}$ of water. Since this is a low air-entry pressure, it is very likely that during the air-sparging remediation process air channeling occurs, as seen in all 18 laboratory experiments carried out by Clayton (1998).

It is important to realize that the mechanism of contaminant removal, in bypassed regions both in homogeneous and heterogeneous porous media, is severely diffusion limited (Clayton, 1998; Ji et al., 1993; Chao et al., 1998; Brusseau 1991). Plummer et al. (1997) observed channeling in their 2-D homogeneous, medium-grained glass bead model and a homogeneous sand pack of comparable 


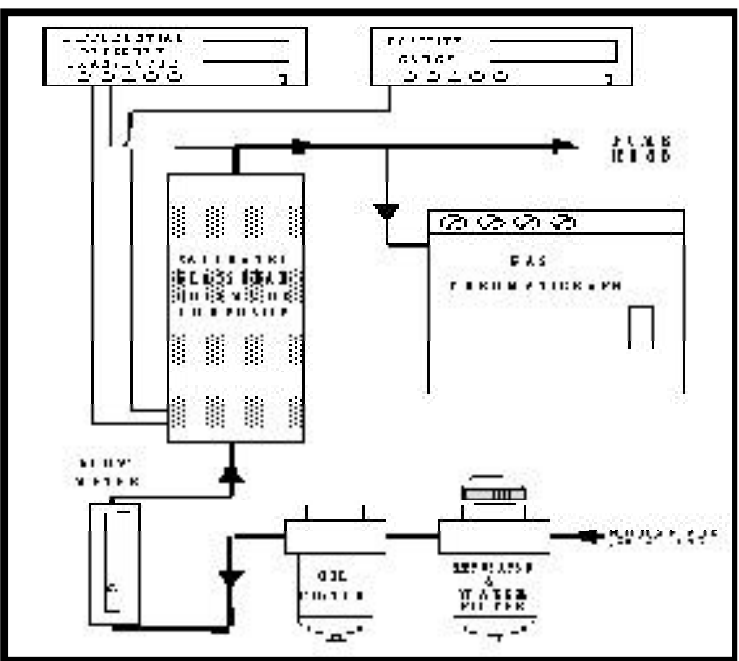

Figure 1a. Schematic of experimental setup.

permeability, density, and porosity, representing both horizontal and vertical well configurations. The air distribution was more uniform for the horizontal well, suggesting that more of the porous media is impacted by air flow. McKay and Acomb (1996) and Schima et al. (1996) used a neutron moisture probe and cross-bore hole resistivity, respectively, to measure the percentage of fluid displaced and air distribution during air sparging at two wells in a homogeneous formation consisting of uniform sands. They observed an initial rapid lateral expansion followed by consolidation of the region. They also observed inconsistent readings in less permeable, heterogeneous formations, indicating the inconsistent behavior of airflow in such formations.

Chao et al. (1998) have estimated water-to-air mass transfer for a number of volatile organic compounds (VOCs) during air sparging in soil columns packed with coarse, medium, and fine sand or glass beads. They used a reactor model to simulate the interface mass transfer alone. They assumed that the concentration in the bulk phase remains constant due to slow diffusion of VOC from the aqueous phase into the air-water interface, as compared to rapid volatilization of VOCs at the air-water interface. Their results indicated that, depending on the VOC sparged, the estimated fraction of total volume affected by air sparging varied from 5 to $20 \%$ for fine sand, but may be as high as $50 \%$ for coarse sand, where more channels are expected to form. This observation has been made by others (Ji et al., 1993; Clayton, 1998; Adams and Reddy, 2000). However, higher air saturation may not necessarily lead to higher contaminant recovery in heterogeneous media, due to air channeling and bypassing of the lower permeable zones.

Ahlfed et al. (1994) have conceptually described the air-sparging process and note that in heterogeneous, stratified formations in which sparging is often applied, the pattern of air movement through the subsurface is complex. This complexity is largely driven by variation in grain size, capillary resistance, and intrinsic permeability of the porous media. In addition, operating parameters such as airflow rate and injection pressure, as well as depth and cross-sectional area of injection, will also affect the contaminant 


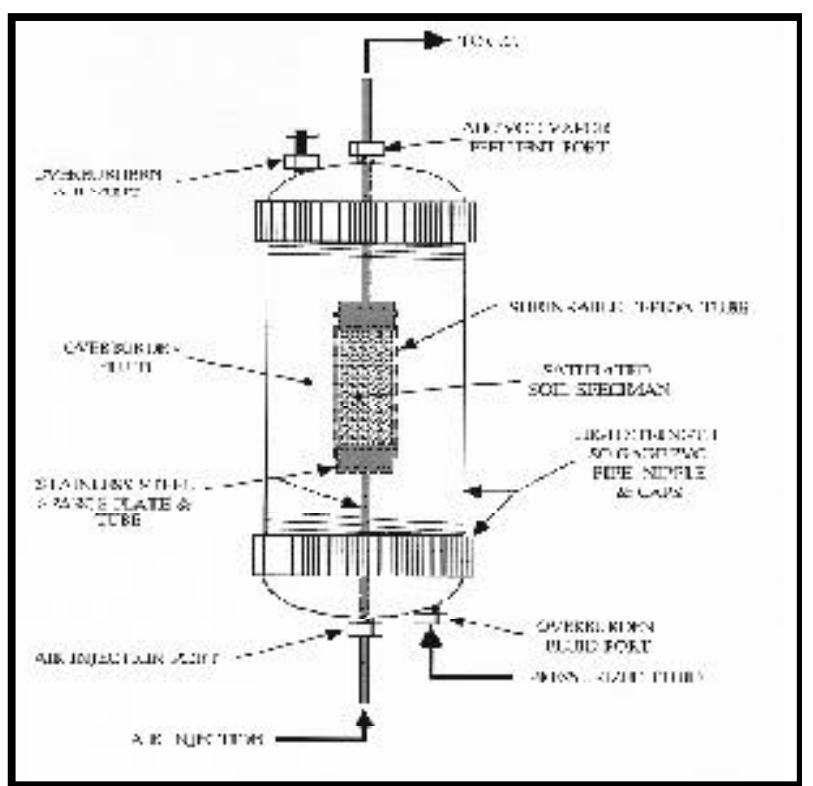

Figure 1b. Composite core assembly in a Hassler cell.

recovery process. To date, no laboratory study has specifically involved heterogeneous core studies. Hence, the authors hope the laboratory results presented here on comparison between contaminant recoveries in relatively homogeneous and heterogeneous porous media, and the proposed foam injection, instead of air injection, could improve the contaminant recovery for an airsparging process. The proposed improved process may also decrease remediation or cleanup time, which is an important concern during field operations.

\section{EXPERIMENTAL AND NUMERICAL MODELS}

\section{a. Experimental Setup and Procedure}

To study contaminant recovery in a relatively homogeneous porous media, a clear acrylic pipe is packed with fine glass beads with an average grain diameter of 67 microns (Figure 1a). Both ends of the column are sealed with recessed end caps around the inlet and outlet to prevent leakage. A 40micron, sintered-bronze filter ( $0.32 \mathrm{~cm}$ in diameter and length) positioned at the inlet of the column's end cap represents the slotted portion of a sparge well used to distribute air into the well. A $11.4 \mathrm{~cm}$-long sealed acrylic pipe is connected to the top of the packed column to provide void space for the water to swell (rise due to displaced volume by air). This assembly is referred to as the packed column from here on. A positive pressure transducer and a differential pressure transducer are used to measure inlet pressure and pressure drop across the packed column. The dry air flow rate is controlled and measured accurately by a digital flow system. A gas chromatograph is used to sample the contaminated effluent air periodically. Since the relative contaminant recoveries, rather than absolute recoveries, are of interest, the sampling is performed until about $90 \%$ of the contaminant is removed. The packed column is cleaned at the completion of each run by flushing it with warm water and hot air for several days, until the effluent air is free of detectable TCA contamination. Use of solvents is prohibited since solvent residuals can cause measurement error. 


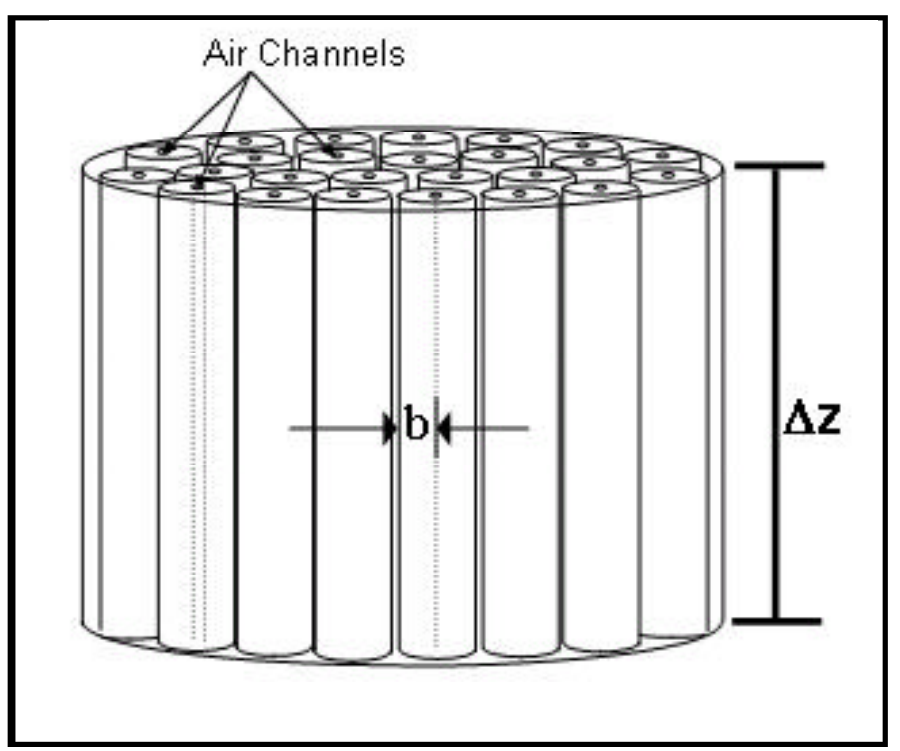

Figure 2. Annular aqueous and air-channel regions of model.

To study contaminant recovery in heterogeneous porous media, a composite core model is used. The core samples, taken from the site of interest, are composed of silty sand, sandy siltstone, silty sandstone and fine to coarse-grained sandstone. The composite core assembly consists of three core samples, cut either vertically or horizontally. A sleeve of heat-shrinkable Teflon ${ }^{\mathrm{TM}}$ tubing is slid over the composite cores, with screens and end plates at the two ends, to hold the sand grains in place. The composite cores are then housed in a Hassler pressure cell (Figure 1b). Mineral oil is used for application of overburden pressure. Properties of all three laboratory models are given in Table 1.

Benzene, toluene, ethyl benzene, and xylene (BTEX) constitute the largest regulated portion of gasoline contamination. In an effort to reduce the number of variables in the laboratory study, focus was primarily on the remediation of benzene, the most stringently regulated contaminant. However, due to the health hazard associated with exposure to benzene, 1,1,1 trichloroethane (TCA) was selected as a suitable alternative to benzene since it has similar solubility, vapor pressure, and Henry's constant (ratio of vapor pressure to solubility). Other properties such as molecular weight, density, boiling point, melting point, and specific heat were also considered for comparison. Table 2 presents a

Table 1. Glass bead-packed column and cores properties.

\begin{tabular}{|c|c|c|c|}
\hline $\begin{array}{c}\text { Porous Media } \\
\text { Properties }\end{array}$ & $\begin{array}{c}\text { Glass Bead- } \\
\text { Packed Column }\end{array}$ & $\begin{array}{c}\text { Vertical } \\
\text { Composite Core }\end{array}$ & $\begin{array}{c}\text { Horizontal } \\
\text { Composite Core }\end{array}$ \\
\hline Length $(\mathrm{cm})$ & 61 & 14.14 & 15.06 \\
\hline \hline Diameter $(\mathrm{cm})$ & 5.715 & 2.54 & 2.54 \\
\hline Permeability, $\mathrm{k}(\mathrm{md})$ & 0.386 & 15.2 & 52.1 \\
\hline \hline Porosity, $\phi(\%)$ & 36.3 & 24 & 35.5 \\
\hline Pore volume, $\mathrm{ml}$ & 448 & 26.1 & 23.5 \\
\hline
\end{tabular}




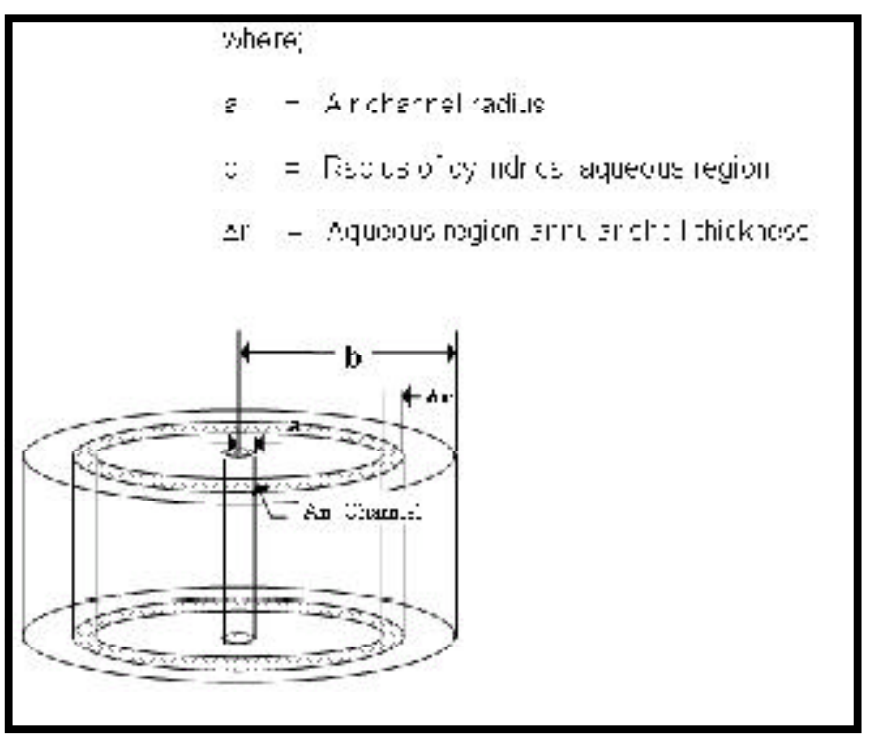

Figure 3. Annular shells within a single aqueous region.

comparison of the chemical properties of benzene with cyclohexane, toluene, and 1,1,1 TCA; chemicals used as suitable alternatives to benzene. Because the contaminant is in the dissolved phase, its specific gravity does not play an important role, and the experimental results can be applied to the remediation of both light and dense nonaqueous-phase liquids (LNAPL and DNAPL).

Both the packed column and composite cores are saturated with a solution of water and TCA, at concentrations of 10, 25, and $50 \mathrm{ppm}$ (by volume). Low-pressure air at 1.41-1.68 atm (6-10 psig) is injected through the bottom of the saturated packed column or the composite-core assembly. Air contaminated with TCA then flows to the top where it is sampled intermittently by a gas chromatograph

Table 2. Properties of some comparable contaminants.

\begin{tabular}{|c|c|c|c|c|}
\hline Properties & $\begin{array}{c}\text { Benzene } \\
\mathrm{C}_{6} \mathrm{H}_{6} \\
\end{array}$ & $\begin{array}{c}\text { Cyclohexane } \\
\mathrm{C}_{6} \mathrm{H}_{12}\end{array}$ & $\begin{array}{c}\text { Toluene } \\
\mathrm{C}_{7} \mathrm{H}_{8} \\
\end{array}$ & $\begin{array}{c}\text { Trichloroethane } \\
\mathrm{C}_{2} \mathrm{H}_{3} \mathrm{Cl}_{3} \\
\end{array}$ \\
\hline Solubility & $1.77 @ 25^{\circ} \mathrm{C}$ & $58 @ 25^{\circ} \mathrm{C}$ & $0.53 @ 25{ }^{\circ} \mathrm{C}$ & $4.4 @ 20^{\circ} \mathrm{C}$ \\
\hline $\begin{array}{l}\text { Vapor pressure } \\
(\mathrm{kPa}) @ 25^{\circ} \mathrm{C}\end{array}$ & 12.7 & 13.1 & 3.8 & 16.5 \\
\hline $\begin{array}{l}\text { Molecular weight } \\
\qquad(\mathrm{g} / \mathrm{mol})\end{array}$ & 78.11 & 84.16 & 92.14 & 133.4 \\
\hline Melting point $\left({ }^{\circ} \mathrm{C}\right)$ & 5.5 & 6.5 & -95 & -30 \\
\hline Boiling Point $\left({ }^{\circ} \mathrm{C}\right)$ & 80.1 & 81 & 111 & 74 \\
\hline Density (g/ml) & 0.8765 & 0.7785 & 0.8669 & 1.3303 \\
\hline $\begin{array}{c}\text { Specific heat } \\
\left(\mathrm{J} / \mathrm{g}-\mathrm{K} @ 25{ }^{\circ} \mathrm{C}\right)\end{array}$ & 1.74 & 1.84 & 1.71 & 1.08 \\
\hline $\begin{array}{c}\text { Henry's constant } \\
\left(\text { dimensionless@25 }{ }^{\circ} \mathrm{C}\right)\end{array}$ & 0.23 & 7.88 & 0.27 & 0.18 \\
\hline
\end{tabular}




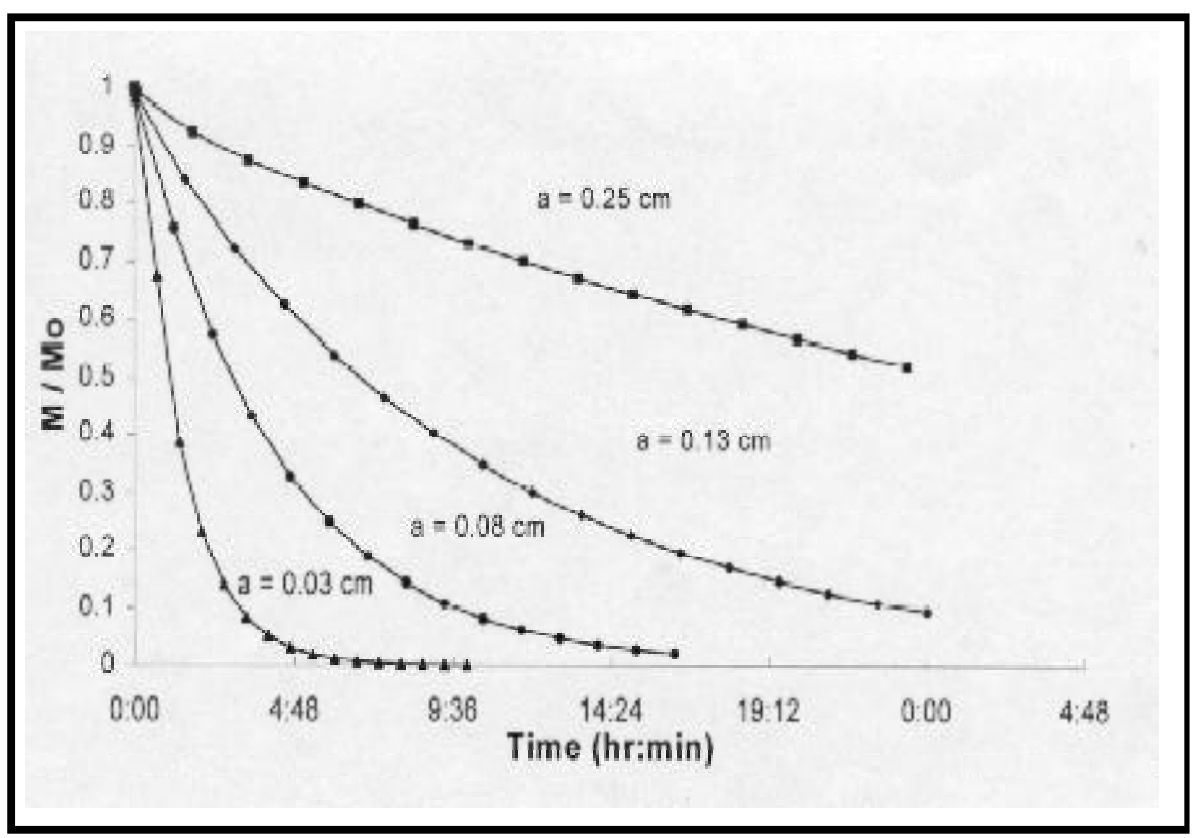

Figure 4. Normalized residual mass vs. remediation time ("a" is varied).

(Figure 1a) at intervals of 3-14 minutes (3 minutes representing the minimum possible sampling time during the early part of the removal curve where the removal rate is highest). The TCA contaminant removal rates at injection flow rates of 15,20 , and $30 \mathrm{ml} / \mathrm{min}$ are measured. All measurements are performed at room pressure and temperature.

\section{b. Numerical Model Description}

Analytical and numerical models provide insight into the air-sparging mass transfer process. Rabideau and Blayden (1998) have reviewed the literature on modeling work done on air sparging and have categorized the numerical models into two types:

1. Mechanistic models, or multi-dimensional, partial differential equations, known also as compositional multidimensional models for fluid flow and contaminant removal studies. These numerical models are commonly used in the oil industry due to the availability of extensive site characterization. Collecting such data is usually not cost-effective for remediation sites where operation costs are minimized and comprehensive site characterizations are not available.

2. Reactor models, on the other hand, are simpler and can simulate mass removal, volume of fluid circulating through the source zone, and air-channel development.

A number of investigators have used a mechanistic model to simulate air sparging. But as Clayton (1998) points out, multiphase flow simulations are unable to handle air channeling without special considerations to represent flow in individual stream tubes, which are not interconnected.

A reactor model based upon past visual studies, which simulated flow dynamics of air sparging (Ji et al., 1993) and Wilson's (1992) proposed general n-compartment model, is developed in this study. Between the advective air-channel regions of the soil column, VOC liquid-phase transport, 


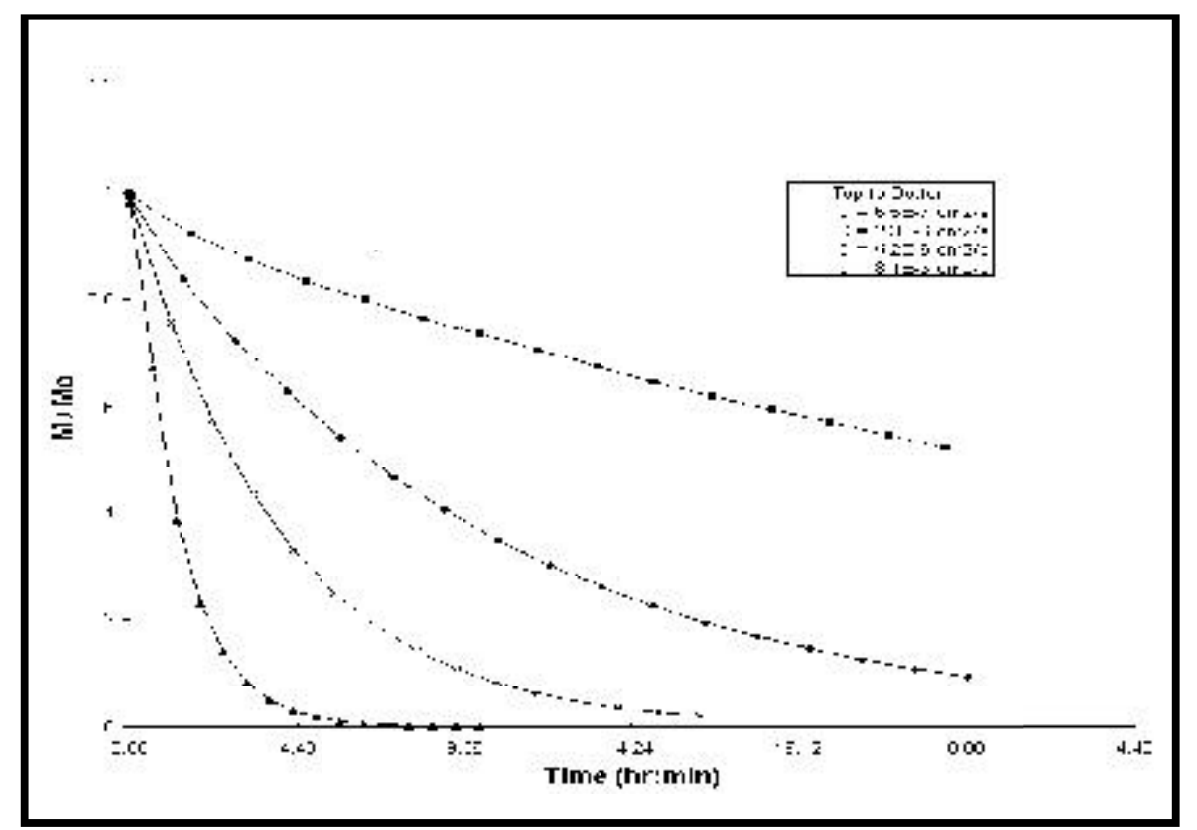

Figure 5. Normalized residual mass vs. remediation time (" $\mathrm{D}$ " is varied).

as simulated by the model, is assumed to be diffusion limited. To facilitate data analysis, the model is written using visual basic application. The numerical model has the capability to simulate the cycling on and off of the sparge system, a practice generally accepted to reduce costs and increase remediation efficiency (Hinchee, 1994; McKay and Acomb, 1996; Reddy and Adams, 1998). In addition, the model can be used to predict the extent of post-remedial contaminant rebound by simulating groundwater contaminants as they diffuse towards equilibrium concentrations. About $61 \%$ of 49 air-sparge case studies evaluated by Bass et al. (2000) showed poor performance (not sufficient for site closure) due to substantial rebound following an initial contaminant concentration reduction. Generally, a period of 6-12 months is required for rebound to fully develop. In some cases, this rebound may be related to a rise in the water table, and hence desorption of contaminant. However, our results show that the slow diffusion of contaminants towards air channels may be more responsible for rebound of dissolved contaminant concentration, as also indicated by Rabideau et al. (1999).

Because the water velocity is negligible, the aqueous-phase dispersion is neglected (McCray and Falta, 1977). The contaminant vaporizes at the interface, and its distribution within the air channel is assumed to be instantaneous and thus is considered to be an equilibrium process, described by Henry's law (Equation 1). Our measurements indicate that equilibrium is not reached in the early part of contaminant recovery curves, when advection forces are predominant.

$$
C^{g}=K_{h} C^{l}
$$




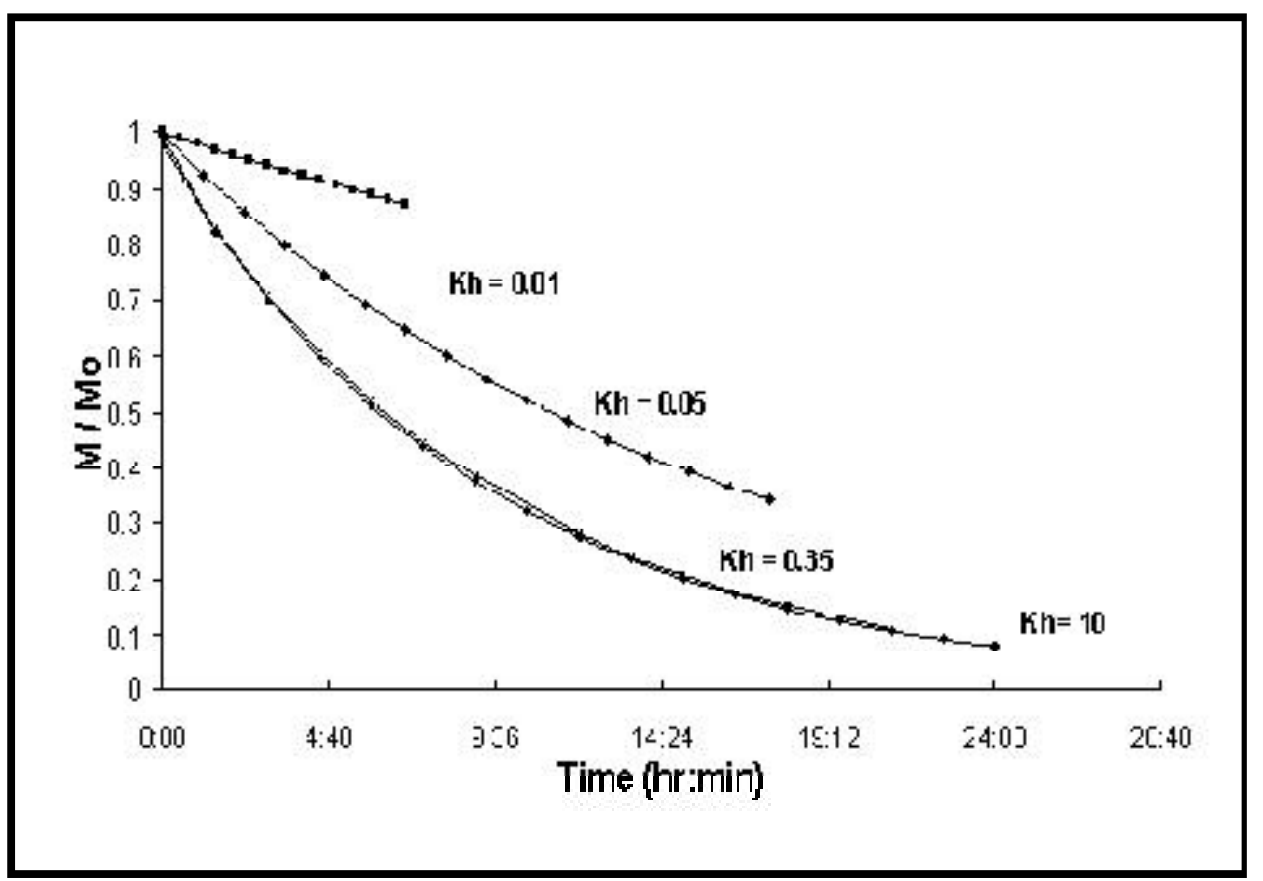

Figure 6. Normalized residual mass vs. remediation time ("Kh" is varied).

where

${ }_{C}^{g}=$ Molar concentration of compound in gas phase $-\left(\mathrm{g}\right.$ moles $\left./ \mathrm{m}^{3}\right)$

${ }_{C}^{l}=$ Molar concentration of compound in liquid phase $-\left(\mathrm{g}\right.$ moles $\left./ \mathrm{m}^{3}\right)$

$K_{h}=$ Henry's law constant - dimensionless

Based on work performed by Wilson et al. (1992), and Roberts and Wilson (1993), the soil column is modeled as a composite of evenly spaced cylindrical air channels with a surrounding, non-advective aqueous region (a radius of " $b$ ") as illustrated in Figure 2. All air-channel and cylindrical aqueous regions are equal in length and circumference. The soil column of height, "h," is divided into equal, vertical-length $(\Delta z)$ sections as shown in Figure 2. Figure 3 illustrates how each cylindrical, aqueous region in each soil column element is divided into equal-thickness $(\Delta \mathrm{z})$ annular shells. Additionally, a tortuosity parameter ( $\mathrm{L}_{\mathrm{path}}$ or path-length coefficient) is used to model the parallel air channels as tree-like air channels observed by investigators.

Combining Fick's first law of binary diffusion with Henry's law, and with equations describing the geometry, results in the following equation, which represents the diffusion transport of the contaminant through the aqueous region.

$$
\begin{gathered}
\frac{d C^{w}}{d t}=\frac{\dot{M}}{V o l}=\frac{2 \pi \Delta z D}{\phi \Delta r \Delta V_{j}}\left[-r_{j+1}\left(C^{w}{ }_{j}-C^{w}{ }_{j+1}\right)+r_{j}\left(C^{w}{ }_{j-1}-C^{w}{ }_{j}\right)\right] \\
\phi \quad=\text { Soil porosity }-\left(\mathrm{L}^{3} / \mathrm{L}^{3}\right) \\
V o l=\text { Volume }-\left(\mathrm{L}^{3}\right) \\
\left.C^{w}=\text { Concentration of the contaminant in the solvent (water }\right)-\left(\mathrm{m} / \mathrm{L}^{3}\right)
\end{gathered}
$$




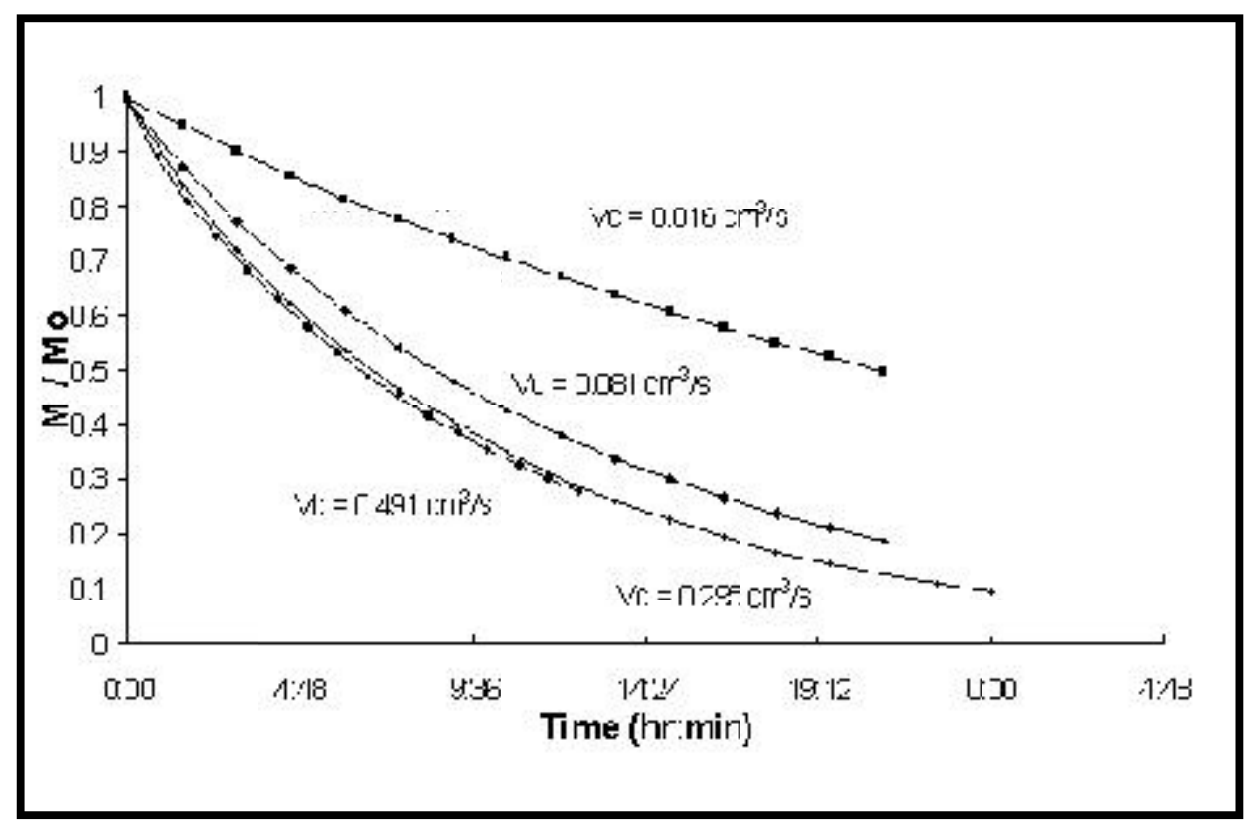

Figure 7. Normalized residual mass vs. remediation time ("Vc" is varied).

The following equation represents the contaminant transport once it has entered the air channel.

$$
\frac{d C^{g}}{d t}=\frac{-4 D\left(C_{i}^{g} / K_{h}-C^{w} n\right)}{\phi a \Delta r}+\frac{V_{c}\left(C_{i+1}^{g}-C_{i}^{g}\right)}{\phi \pi a^{2} \Delta z(\text { Channel \# })}
$$

For details of the numerical model, the reader is referred to Drucker, 1995; Drucker and Di Julio,1996; and Wilson et al., 1992.

\section{c. Foam Injection to Reduce Air Mobility}

The capacitance or dead-end pore model was originally proposed to explain the concentration "tail" observed in breakthrough curves of displacements. This tail is more pronounced in carbonate than in sandstone because the pore structure of a typical carbonate is more heterogeneous (Raimondi and Torcaso, 1964; Stalkup, 1970; Shelton and Schneider, 1975; Spence and Watkins, 1980). Similarly, we have observed the more pronounced tailing phenomenon here when the results of contaminant recovery for packed column are compared with that of the core, even though the contaminant exists as a dissolved phase only. This leads one to believe that in our study air channeling, or bypassing, in heterogeneous cores resulted in an inefficiency in contaminant recovery, leading into longer recovery times than for the relatively homogeneous packed column. This is also supported by results of the sensitivity analysis on "a" (air channel radius), as seen in the Results section.

The air-channeling problem associated with heterogeneity may be remedied using foaming surfactants, which tend to encapsulate air and form foam (increased numbers of air bubbles' surface area to volume, Burns and Zhang 2001). The reduction of air mobility increases air residence time and the contact area between air and the contaminated water, which can result in improved contaminant recovery. Foams are formed by dispersion of gas bubbles in liquids. Such dispersions are 


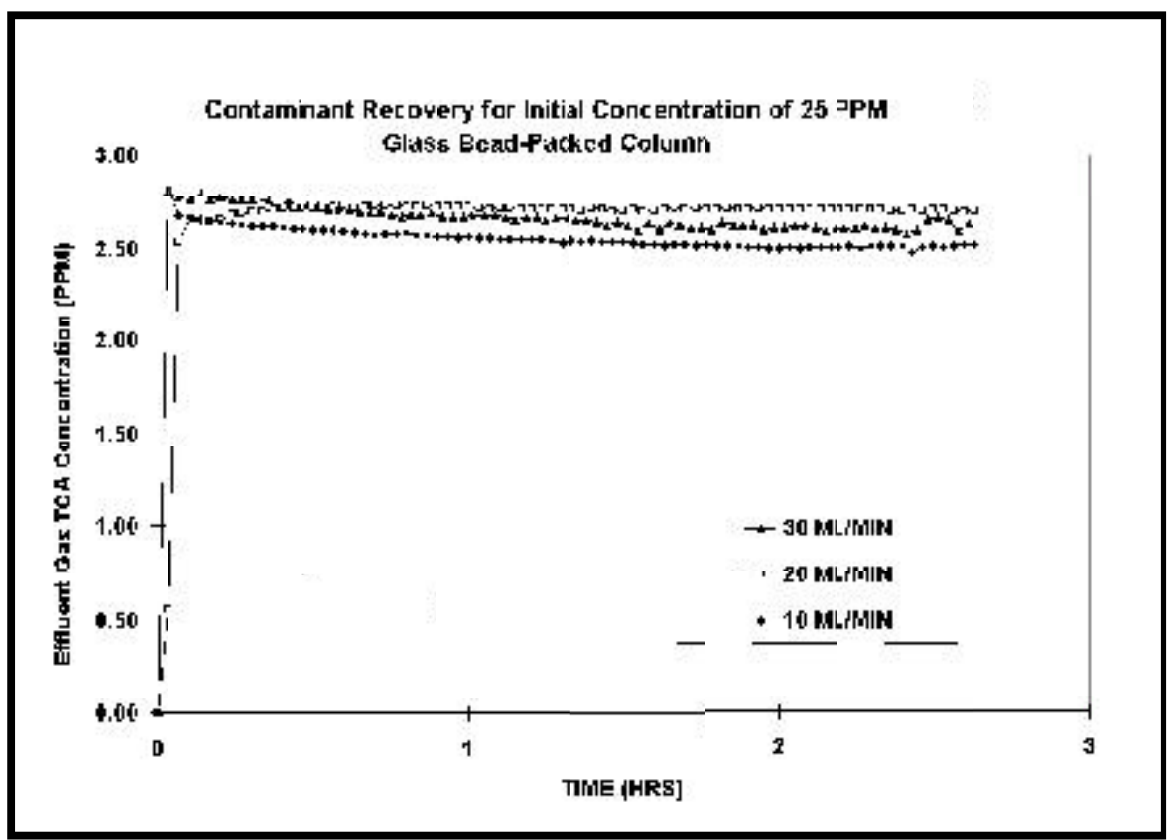

Figure 8. TCA recovery for initial concentration of $25 \mathrm{ppm} —$ glass bead-packed column.

normally quite unstable, unless surfactant is added to the liquid, which greatly improves stability due to a decrease in surface tension. Previous foam studies in reservoir engineering have demonstrated the tendency of foams to preferentially plug channels or higher permeable regions in porous media. Additionally, air mobility is reduced via an increase in air viscosity and a decrease in air relative permeability (a reduction as high as 200-600 fold), while gas saturation remains unchanged (Khan, 1965; Bernard and Holm, 1964). This is attributed to blocking of pore throats by gas films. In the case considered here, the average bubble size is larger than the pore diameter, and thus foam flows as a progression of films that separate individual gas bubbles. Some of the undesirable features of surfactant, such as sensitivity to highly saline brine, temperature, contaminant type, and retention, need to be considered when surfactants are selected for a given site.

In a parallel core flood study involving two cores with different permeabilities, Di Julio and Emanuel (1989) demonstrated the ability of foam to reduce gas mobility by plugging channels in the higher permeable core and diverting gas to the lower permeability core. The foam injection resulted in an incremental oil recovery improvement of $33.6 \%$. Likewise, it is expected that foam injection in the airsparge process will reduce air mobility and hence provide a significant reduction in contaminant recovery time.

\section{RESULTS}

\section{a. Sensitivity Analysis Using a Numerical Model}

A sensitivity analysis was performed by varying several parameters and observing their impact on the normalized residual mass of contaminant. The variables used to conduct the analysis are "a" (air-channel radius), "D” (diffusion coefficient), " $\mathrm{K}_{\mathrm{h}}$ " (Henry's constant), and " $\mathrm{V}_{\mathrm{c}}$ " (air-injection flow rate). Results of this analysis are presented in Figures 4-7. 


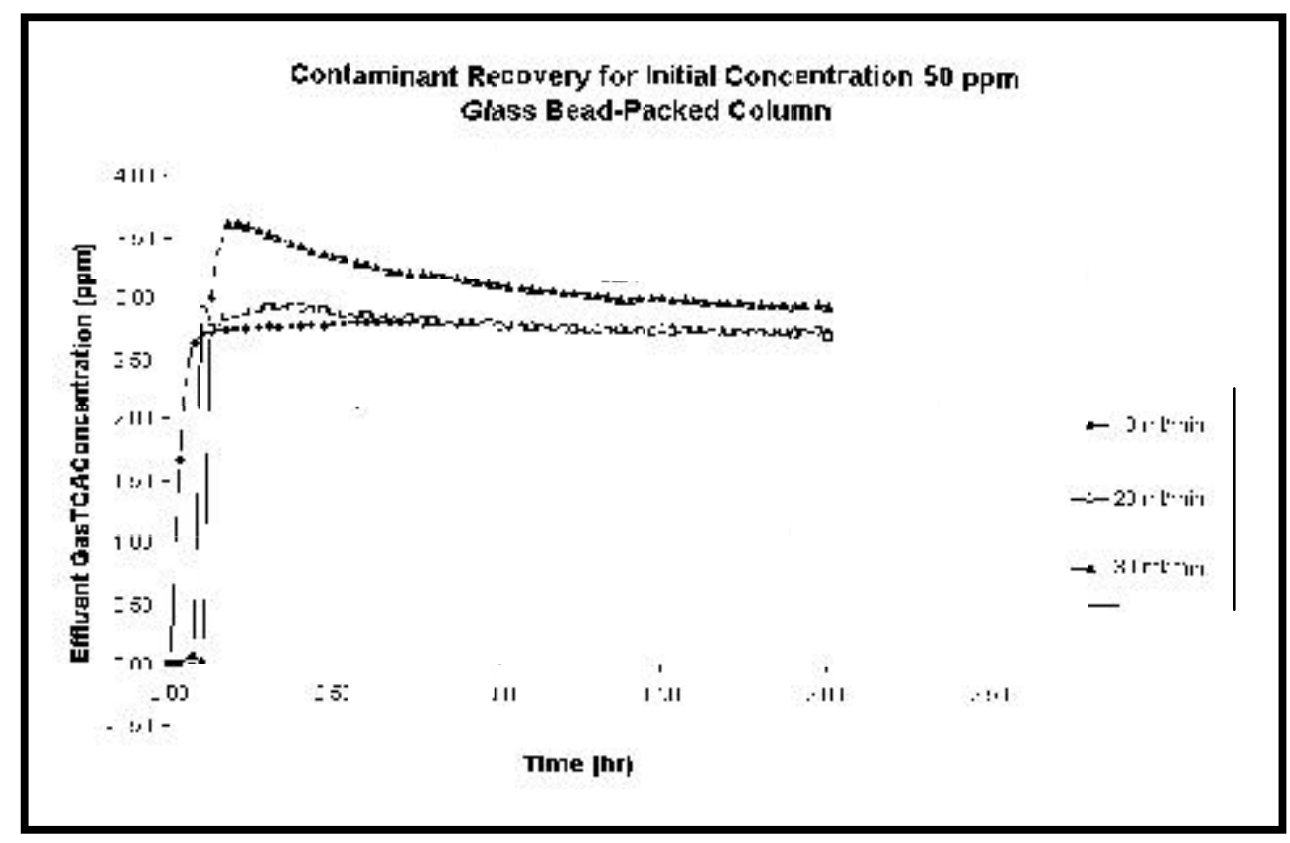

Figure 9. TCA recovery for initial concentration of $50 \mathrm{ppm}$-glass bead-packed column.

Normalized values of residual mass, $\mathrm{M} / \mathrm{M}_{\mathrm{o}}$, for a given range of "a" are shown in Figure 4. As the air-channel radius, a, is changed, it proportionally affects " $b$," the radius of the aqueous region surrounding the air channel. For instance, if "a" is decreased, "b" is also decreased (due to an increase in air-channel number density), causing the remediation rate to improve. Therefore, to improve contaminant-removal efficiency, it is desirable to promote a relatively large number of air channels, having small radii within a given volume of saturated soil. In the limit, this may be represented by evenly distributed air saturation within a given zone.

The diffusion coefficient, $\mathrm{D}$, has no direct bearing on the channel geometry but has a significant effect on the contaminant-removal rate. Most VOC diffusion coefficients will fall in the range between $2.54 \mathrm{E}-7$ and $3.0 \mathrm{E}-6 \mathrm{~cm}^{2} / \mathrm{s}$. Contaminant removal rates in the form of $\mathrm{M} / \mathrm{M}_{\mathrm{o}}$ are illustrated in Figure 5. It is evident that the increase in D improves the contaminant-removal rate. This result is expected since the model is diffusion limited.

The effect of Henry's constant, $\mathrm{K}_{\mathrm{h}}$, on air-sparging remediation efficiency is shown in Figure 6. In this particular case, Henry's constant has an upper limit of approximately 0.35 (i.e., $\mathrm{M} / \mathrm{M}_{\mathrm{o}}$ for the case with $\mathrm{K}_{\mathrm{h}}$ of 10 closely resembles that for $\mathrm{K}_{\mathrm{h}}$ of 3.5 ). The lower boundary of $\mathrm{K}_{\mathrm{h}}$ values, such as $\mathrm{K}_{\mathrm{h}}=0.01$, illustrates how a relatively low volatilization ratelimit the contaminant-removal rate. Therefore, an analysis such as this can be useful in determining the effectiveness of air sparging on the removal rate of contaminants with lower values of $\mathrm{K}_{\mathrm{h}}$, such as semi-volatile organic solvents.

The volumetric flow rate of injected air has a direct bearing on the air saturation, within saturated soil. It is expected that an increase in airflow rate will increase the air saturation, and hence increase the number and diameter of the air channels. However, to investigate only the effect of air volumetric flow rate on rate of contaminant removal, air saturation is held constant, while the flow 


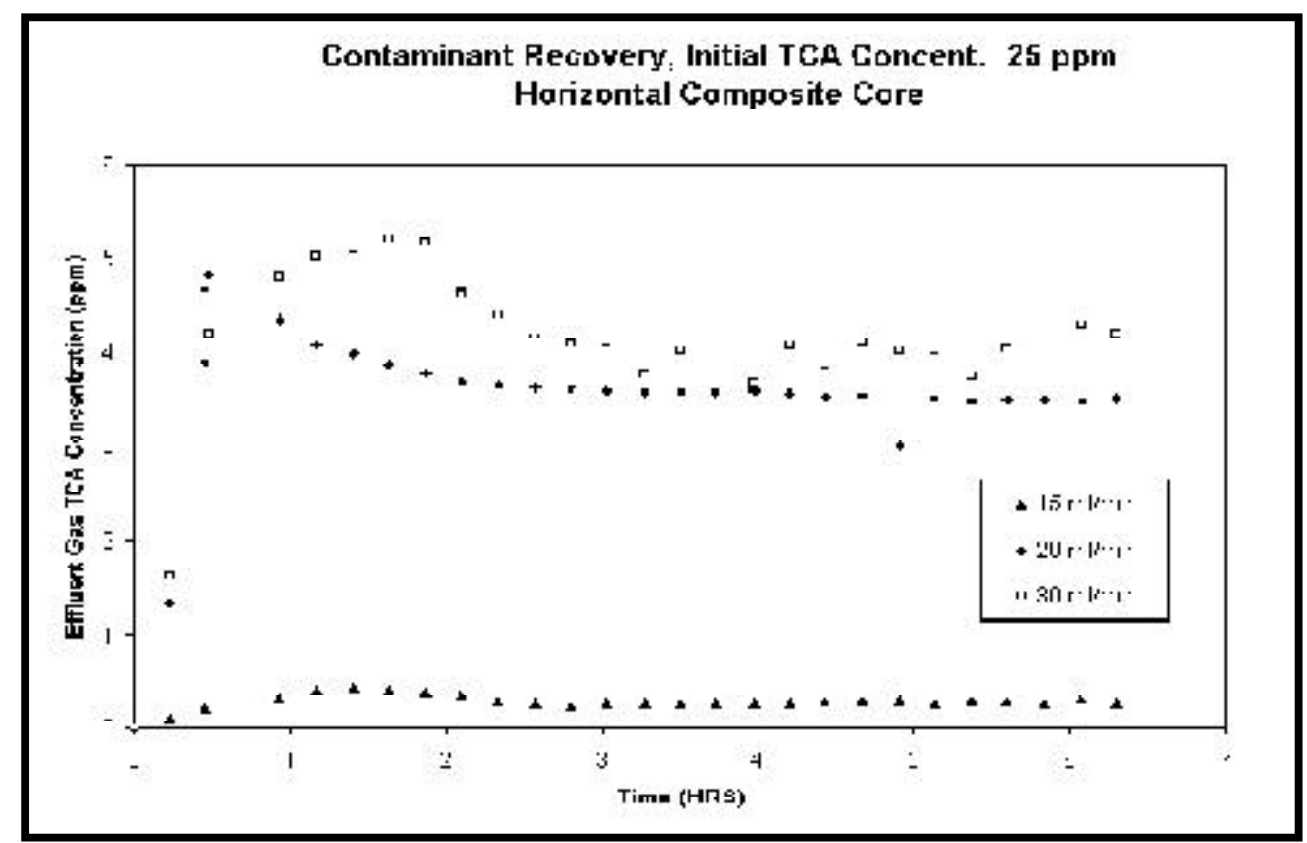

Figure 10. TCA recovery for initial concentration of $29 \mathrm{ppm}$ - horizontal composite core.

rate is raised or lowered, as shown in Figure 7. The lower limit of air flow, $\mathrm{Vc}=0.016 \mathrm{~cm}^{3} / \mathrm{s}$, in Figure 7, is an example of flow rate becoming too small to efficiently remove the contaminant volatilized in the air channel. Lower limits of airflow such as this are encountered at the perimeter of a sparge well's region of influence. The upper limit of effectiveness of raising the airflow rate is realized at or slightly less than $\mathrm{Vc}=0.295 \mathrm{~cm}^{3} / \mathrm{s}$. Therefore, air injection greater than $0.295 \mathrm{~cm}^{3} / \mathrm{s}$ will only serve to increase cleanup costs associated with sparging the contaminated groundwater. This is an important observation, since the air-sparging process is a diffusion-limited process. An increase in air-injection flow rate will not have a significant effect on the rate of contaminant diffusion and removal, but may only improve the vaporization (according to Henry's law) and hence its subsequent advection by air.

\section{b. Laboratory Results}

The removal rate is believed to be controlled by the two distinct processes of advection and diffusion. Initially the rate of contaminant removal is controlled by advection. Contaminant is removed by relatively quick vaporization from the air channel wall and subsequent advection by air, until the contaminant concentration in the air channel reduces below that in the aqueous phase, at which time the diffusion process will begin to dominate the removal rate. These two regions of flow regimes, advection-controlled and diffusion-controlled, are seen as the initial peaks followed by an asymptotic behavior in all of our contaminant-removal curves.

Contaminant recovery in the packed column was measured at three different air-injection flow rates $(10,20$, and $30 \mathrm{ml} / \mathrm{min})$ for three different initial concentrations $(10,25$, and $50 \mathrm{ppm}$ TCA in water). Figure 8 shows the contaminant recoveries at three different flow rates for initial concentration of $25 \mathrm{ppm}$. Figure 9 


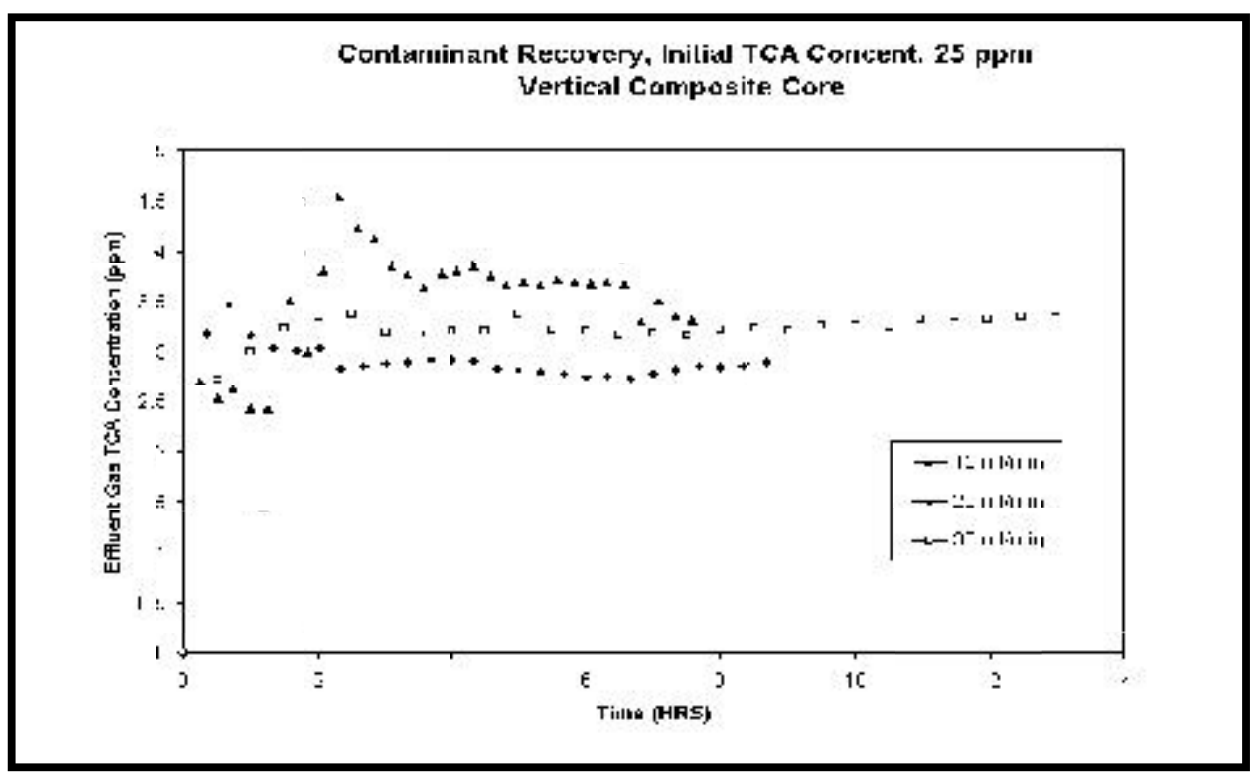

Figure 11. TCA recovery for initial concentration of $25 \mathrm{ppm}$-vertical composite core.

is a similar curve for a 50-ppm initial concentration. Results in Figure 8 indicate that the rate of TCA removed increased when the air-injection flow rate was increased from $10 \mathrm{ml} / \mathrm{min}$ to $20 \mathrm{ml} / \mathrm{min}$. The rate of recovery decreased, however, when the air-injection flow rate was further increased to $30 \mathrm{ml} / \mathrm{min}$. This indicates that the optimum air-injection rate is below $30 \mathrm{ml} / \mathrm{min}$ for this case. The optimum airinjection rate for initial concentrations of $10 \mathrm{ppm}$ and $50 \mathrm{ppm}$ were, respectively, around $10 \mathrm{ml} / \mathrm{min}$ and $30 \mathrm{ml} / \mathrm{min}$. This observation was confirmed earlier by the simulation results when it was shown that the increase in air-injection flow rate did not have a significant effect on the rate of contaminant diffusion and removal, but may only improve vaporization and subsequent advection. Comparing contaminant recovery for initial contaminant concentrations of $50 \mathrm{ppm}$ and $25 \mathrm{ppm}$ at an airflow rate of $20 \mathrm{ml} / \mathrm{min}$, the higher peak for $50 \mathrm{ppm}$ indicates higher convective recovery very early on. However, this higher recovery is not sustained during the second portion of the curve, which is diffusion limited, shown as the asymptotic recovery leading to a lower overall percentage recovery (43\% as compared with 49\%). To test experimental precision each experiment was repeated several times (three to five times for the packed column and three times for core measurements). For measurements on the packed column size of error bars for the rate data varied between $2 \%$ to $5 \%$, while the error in cumulative measurements had an end point error bar of about $8 \%$ (all with $95 \%$ confidence limits). Measurements on the cores showed less reproducibility.

To study the effect of heterogeneity on contaminant recovery, measurements on the packed column may be compared with those from the cores, and also measurements on horizontally cut cores may be compared with those for vertically cut cores, which are more heterogeneous and stratified.

Figures 10 and 11 show results of three air-sparging runs for the horizontal and vertical composite cores at initial contaminant concentrations of $25 \mathrm{ppm}$. Concentrations of the contaminant, TCA, in effluent air, as a function of the three air-injection rates are compared. Results for the horizontal composite core look more like the packed-column run. The contaminant-removal curves 


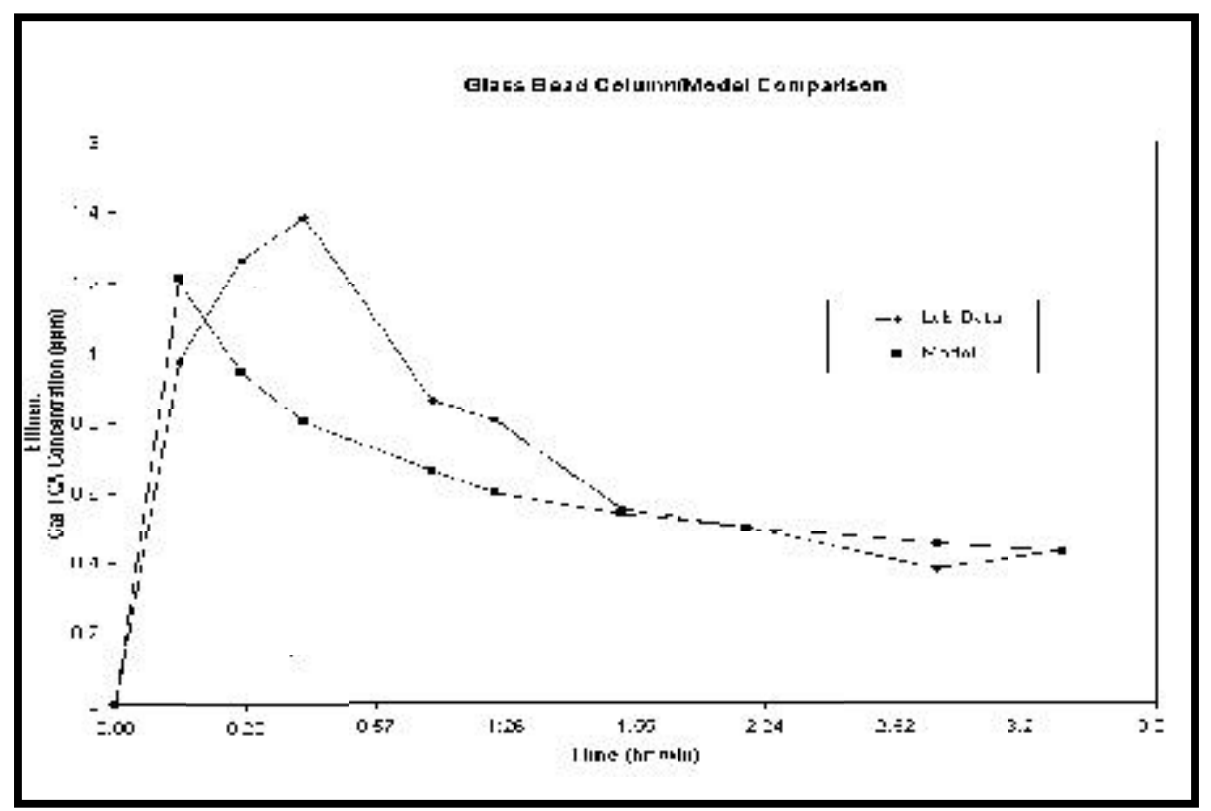

Figure 12. Comparison of laboratory and numericl model results—glass bead-packed column.

are flatter at generally higher concentrations of contaminant and with less tailing effect, as compared with those for the vertical composite core. This behavior could be attributed to the higher heterogeneity of the vertical composite core, where more channeling takes place and hence the removal efficiency is inconsistent and lower. As the initial concentration of contaminant is increased, the optimum flow rate, for which contaminant recovery is maximum, also increases. For example, we observed the optimum flow rate for $10 \mathrm{ppm}$ was $10 \mathrm{ml} / \mathrm{min}$, while that for $25 \mathrm{ppm}$ was about $20 \mathrm{ml} / \mathrm{min}$. We obtained reasonably good reproducibility of the recovery profile and the percent of total contaminant removed, but we had difficulty with cleaning after each run due to TCA adsorption in the cores .

Our experimental results on the packed column show less channeling than our core studies, as seen by the shape of the contaminant-recovery profile and the shorter recovery time (about $4 \mathrm{hr}$ recovery time for the packed column versus $24 \mathrm{hr}$ recovery time for the composite core, estimated based on cumulative recoveries). Note that the packed column has a pore volume which is about 17 to 19 times that of the composite cores, hence the more heterogeneous cores require nearly 100 times more pore volumes of air throughput to achieve similar, cumulative contaminant recoveries.

Air channeling in the more heterogeneous core samples can also be observed when experimental results are compared with the numerical model predictions (which assume the contaminant recovery takes place via air channels). The predicted profile matches the core studies better due to its inherent heterogeneity and hence predominant recovery via air channels. Results of two experiments on packed column and composite cores are compared with numerical model predictions as shown in Figures 12 and 13. Figure 12 for the packed column is at $10 \mathrm{ppm}$ and $15 \mathrm{ml} / \mathrm{min}$; while Figure 13 is for the vertical composite core at $50 \mathrm{ppm}$ and $15 \mathrm{ml} / \mathrm{min}$, initial TCA concentration and air-injection flow rate, respectively. The predicted concentrations are matched with the experimental 
Table 3. Input and Calculated Variables for Simulation

\begin{tabular}{|c|c||c|}
\hline \multicolumn{3}{|c|}{ Glass Bead Input Variables } \\
\hline variable $=$ value & units & description \\
\hline $\mathrm{rad}=1.0000$ & in. & radius of influence \\
\hline $\mathrm{h}=24.0000$ & in. & sparge pt.-water table depth \\
\hline $\mathrm{Vc}=0.01520$ & $\mathrm{cuin} / \mathrm{s}$ & control panel volumetric flow rate \\
\hline $\mathrm{Kh}=0.713$ & $\mathrm{n} / \mathrm{a}$ & Henry's constant \\
\hline $\mathrm{Cjo}=50.00$ & $\mathrm{ppb}$ & initial contaminant concentration \\
\hline $\mathrm{v}=0.36$ & $\mathrm{cuin} / \mathrm{cui}$ & total soil porosity \\
\hline $\mathrm{w}=\mathrm{w} 0.33$ & $\mathrm{cuin} / \mathrm{cui}$ & water-filled soil porosity \\
\hline $\mathrm{D}=1.50 \mathrm{E}-07$ & $\mathrm{spin} . / \mathrm{s}$ & diffusion coefficient \\
\hline \hline $\mathrm{Csat}=1,100,000.00$ & $\mathrm{ppb}$ & contaminant saturation concentration \\
\hline $\mathrm{a}=7.00 \mathrm{E}-02$ & in. & air channel radius \\
\hline $\mathrm{Lpath}=1.4$ & in/in & path-length coefficient $(1 \leq \mathrm{Lpath} \leq 2)$ \\
\hline $\mathrm{dt}=4.20$ & $\mathrm{~s}$ & time interval \\
\hline
\end{tabular}

\begin{tabular}{|c|c|c|c|}
\hline \multicolumn{4}{|c|}{ Glass Bead Calculated Variables } \\
\hline variable $=$ calculation & value & units & description \\
\hline $\mathrm{dz}=\mathrm{h} /$ cell row \# & 2.400 & in. & cell height \\
\hline $\mathrm{b}=\mathrm{rad} /(\text { Chanl\#L } \mathrm{L} \text { path) })^{\wedge} 5$ & 0.404 & in. & nonadvective channel radius \\
\hline $\mathrm{dr}=(\mathrm{b}-\mathrm{a}) / 9$ & 0.037 & in. & nonadvective shell thickness \\
\hline $\mathrm{a}$ factor $=\mathrm{a} / \mathrm{dr}$ & 1.885 & in/in & air channel radius/shell thickness \\
\hline channel\# $=(\mathrm{v}-\mathrm{w}) \mathrm{x}(\mathrm{rad} / \mathrm{a})^{\wedge} 2 / \mathrm{Lpath}$ & 4.373 & $\mathrm{n} / \mathrm{a}$ & air channel number per element \\
\hline ppbfactor $=.001$ if using ppb's & 0.001 & $\mathrm{n} / \mathrm{a}$ & ppb calculation factor \\
\hline $\mathrm{z}=\mathrm{dz} \times \mathrm{j}$ & $\mathrm{n} / \mathrm{a}$ & in. & cell height \\
\hline
\end{tabular}




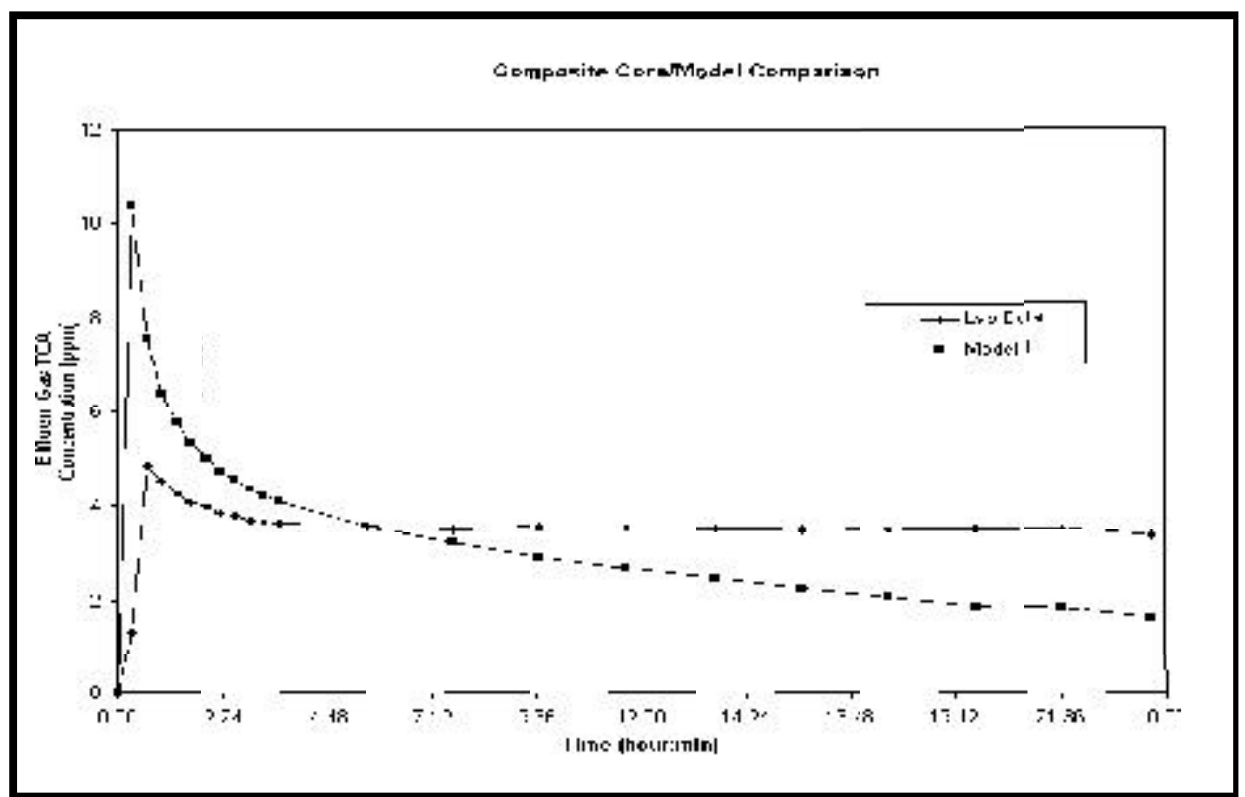

Figure 13. Comparison of laboratory and numerical model results-composite core.

values by varying the parameter " $a$," air channel radius, which in effect also changes the density of air channels, as discussed earlier. Table 3 shows the input and calculated variables used for simulation. Peak values of contaminant concentration are approximately $1 / 4$ to $1 / 10$ of estimated equilibrium values, based on Henry's law, which assumes instantaneous distribution of contaminant within the air channels. As expected, Henry's law provides the upper limit of contaminant concentration in the effluent air. Laboratory results in Figure 13 show a leveling off at 3.5 ppm, after $31 / 3$ hours, while the model prediction tends to asymptotically approach zero-contaminant concentration. This discrepancy may be attributed to dispersion and/or adsorption processes, which were not included in our numerical model. Even with this discrepancy, one may still make a conservative prediction of the air-sparge remediation rate, if one were to scale up the numerical model to simulate air sparging at the field scale.

The existing model has considerable potential for evolving into an accurate field-scale model. Once developed, the field-scale numerical model could be used in the design of a full-size air-sparge system by determining air-sparge well spacing and placement, air-injection rate, injection pressure, and rate of remediation.

Since the numerical model allows for contaminant removal through air channels only, the better match between measurements in the core samples and predictions indicates the existence of channels in heterogeneous samples. Additionally, as discussed earlier, large volumes of air injection are required to recover contaminants in heterogeneous porous media and hence the need for reduction of air channeling. A remedy may be foam injection. 


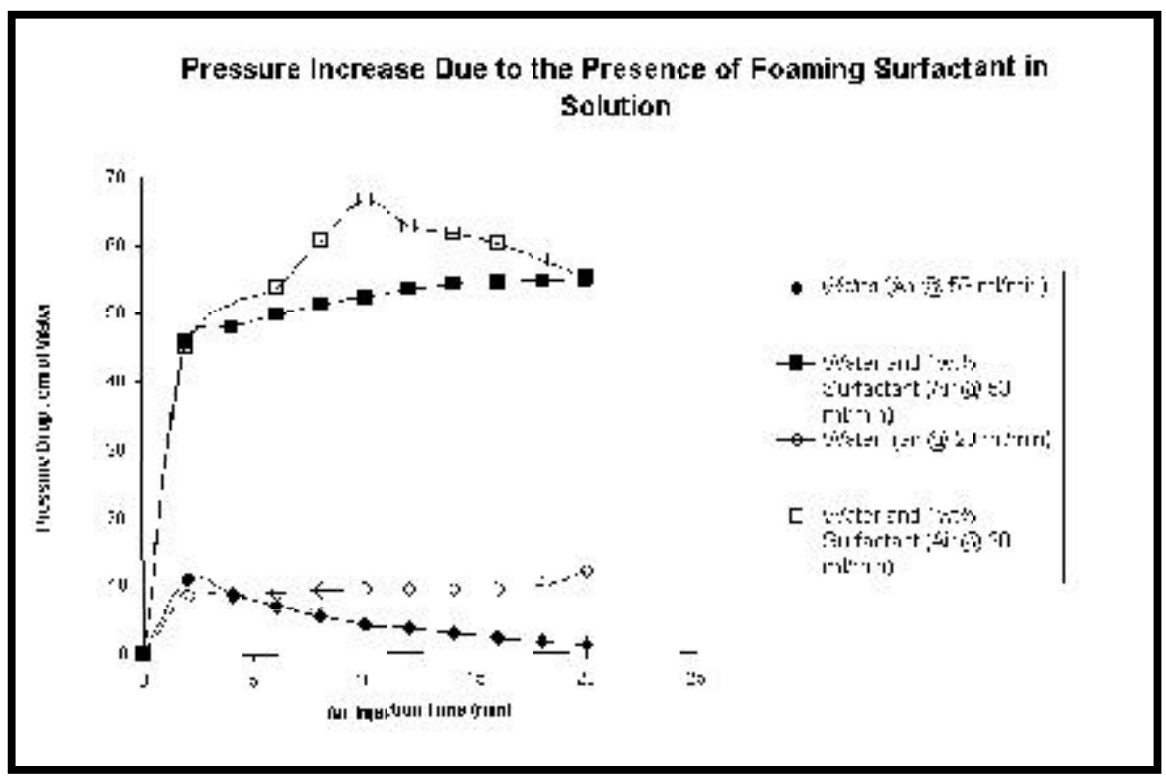

Figure 14. Foam-induced mobility control indicated by increase in pressure drop.

\section{c. Result of Foam Injection}

We used the surfactant Steol CA-460, manufactured by Stepan Company, Northfield, Ill. Steol CA-460 is an alcohol ethoxy sulfate consisting of 15\% denatured ethyl alcohol and 2\% ammonium sulfate. To study the reduction of air mobility in the air-sparging process, the packed column was saturated with water and the pressure drop across the packed column was measured as air was injected into the packed column at a given flow rate. This provided the baseline pressuredrop profile. The packed column was then saturated with a solution of $1 \%$ by weight surfactant in water, and again the pressure drop across the packed column was measured as air was injected. These experiments were run in order to find an optimum injection rate for which the maximum pressure drop in the porous medium may be achieved. Note that we expected some air channeling or bypassing in the packed column, which would be less than that in the composite cores. Figure 14 shows an example of the measured increase in pressure drop when air is injected into the packed column, where surfactant is present. We observed formation of foam within the packed column and an increase in pressure drop by a factor of 20 to 40 on the average, at flow rates of 53 and $20 \mathrm{ml} / \mathrm{min}$, respectively. This drastic increase in pressure drop is attributed to decrease in air relative permeability, which results from reduction of air channels. As seen in previous foam studies, reduction of gas mobility can improve its saturation distribution and hence increase both the contact area and contact time between the air and the contaminant, resulting in improved recovery of the contaminant from porous media.

\section{CONCLUSION}

Laboratory results from glass bead-packed columns and composite cores have demonstrated the effectiveness of air sparging as a remediation process. Two distinct regimes of advective- and diffusion-controlled flows are observed. Measurements on composite cores showed more channeling than 
in the relatively homogeneous packed column. Hence, they required a much longer time for air injection and subsequent contaminant removal.

A numerical reaction model is used to conduct a sensitivity analysis by varying input parameters, including air-channel radius (a), diffusion coefficient (D), Henry's law constant $\left(\mathrm{K}_{\mathrm{h}}\right)$, and injection flow rate $(\mathrm{Vc})$. Results of the analysis illustrate the significance of each parameter with respect to air-sparging feasibility and remediation rate. Model predictions of contaminant removal agree fairly well with laboratory measurement results and indicate the existence of channels in heterogeneous samples, and hence the need for reduction of air-channeling. Use of foaming surfactants is suggested to reduce air mobility in channels and improve air-saturation distribution. This may increase contaminant recovery and reduce cleanup time.

\section{ACKNOWLEDGMENTS}

We wish to thank the Southern California Gas Co. for providing project funding and core samples; the California State University, Northridge, engineering students who helped to construct the laboratory apparatus and to conduct the applicable tests; and Bill Shallenberger for guidance and review of the analysis and laboratory results.

Andrew S. Drucker (adrucke@nfesc.navy.mil) is currently an engineer at the Naval Facilities Engineering Service Center, Point Huneme, Calif. He completed the numerical analysis presented here as his Master's thesis at the aforementioned university. Shoeleh Di Julio (the corresponding author, sdijulio@ecs.csun.edu) is a professor at California State University, Northridge, Mechanical Engineering Department, Northridge, CA 91330-8348.

\section{REFERENCES}

Adams, J. A., and K. R. Reddy 2000. Removal of dissolved-and free-phase benzene pools from groundwater using in situ air sparging. J. of Environ. Eng., v 126, no. 8: 697-707.

Ahlfeld, D.P., A. Dahmani, and W. Ji. 1994. A conceptual model of field behavior of air sparging and its implication for application. Ground Water Monitoring and Remediation, 14, no. 4: 132-139.

Bass, D. H., N. A. Hastings, and R. A. Brown. 2000. Performance of air-sparging systems: a review of case studies. J. of Hazardous Materials, 72, no. 2-3;101-119.

Bernard, G. G., and L. W. Holm. 1964. Effect of foam on permeability of porous media to gas. SPE 986, presented at the Fall Technical Conference and Exhibition of the Society of Petroleum Engineers, Houston, Texas.

Brusseau, M.L. 1991. Transport of organic chemicals by gas advection in structured or heterogeneous porous media: development of a model and application to column experiments. Water Resour. Res., Dec., 27, no. 12: 3189-3199.

Burns, S.E., and N. Zhang. 2001. Effects of system parameters on the physical characteristics of bubbles produced through air sparging. Env. Science and Technology, 35, no. 1:204-208. 
Chao, K. P., S.K. Ong, and A. Protopapas. 1998. Water-to-air mass transfer of VOCs: laboratory-scale, air-sparging system. J. of Environ. Eng., 124, no. 11: 1054-1060.

Clayton, W. S. 1998. A field and laboratory investigation of air fingering during air sparging. Ground Water Monitoring and Remediation, 18, no. 3,134-145.

CRC Handbook of Chemistry and Physics, CRC Press, 73 Edition 1992-1993.

Di Julio, S. S., and A.S. Emanuel. 1989. Laboratory study of foaming surfactant for $\mathrm{CO}_{2}$ mobility control. 1989. SPE Reservoir Engineering, May, 136-142.

Drucker, A. S. 1995. Aliso Canyon site in situ remediation. M.S. thesis. California State University, Northridge.

Drucker, A. S., and S. S. Di Julio. 1996. Groundwater clean up, in situ air sparging: development of a model and application to saturated soil column experiments. Water Environment Federation, WEFTECH'96, 69 ${ }^{\text {th }}$ Annual Conference and Exposition, Dallas, Texas, October 5-9, 1996.

Hinchee, R.E. 1994. Air sparging for site remediation. CRC Press Inc., Boca Raton.

Ji, W., A. Dahmani, D. P. Ahlfeld, J.D. Lin, and E. Hill. 1993. Laboratory study of air sparging: airflow visualization. Ground Water Monitoring \& Remediation 13, no.4: 115-126.

Johnson, R.L., Johnson, P.C., McWhorter, D.B., Hinchee, R.E., and Goodman, I. 1993. An overview of in situ air sparging. Ground Water Monit. Rev., Fall, 127-135.

Kearl, P.M., and Korte, Nic E. 1991. Vapor extraction experiments with laboratory soil columnsimplications for field programs. Waste Management, 121, 231-239.

Khan, S. A. 1965. The flow of foam through porous media. M.S. thesis, Stanford University.

McCray, J.E. and R.W. Falta. 1997. Numerical simulation of air sparging for remediation of NAPL contamination. Ground Water 35, no. 1: 99-110.

McKay, D. J., and L. J. Acomb. 1996. Netron moisture probe measurements of fluid displacement during in situ air sparging. Ground Water Monitoring and Remediation 16, no.4: 86-94.

Plummer, C. R., J. D. Nelson, and G. S. Zumwalt. 1997. Horizontal and vertical well comparison for in situ air sparging. Ground Water Monitoring and Remediation 17, no. 1: 91-96.

Rabideau, A.J., J.M. Blayden, and C. Gaguly. 1999. Field performance of air-sparging system for removing CE from groundwater. Environ. Sci. Technol, 33, no.1: 157-162.

Rabideau, A.J., and J.M. Blayden. 1998. Analytical model for contaminant mass removal by air sparging. Ground Water Monitoring and Remediation, Fall 1998, 120-130.

Raimondi, P., and M. A. Torcaso. 1964. Distribution of oil phase obtained upon imbibition of water. Transaction of the American Institute of Mining and Metallurgical Engineering, 231:49-55.

Reddy, K. R., and J. A. Adams. 1998. System effects on benzene removal from saturated soils and groundwater using air sparging. J. Environ. Eng. 124, no. 3: 288-299. 
Roberts L.A., and D.J. Wilson. 1993. Groundwater cleanup by in situ sparging I. modeling of dense, nonaqueous-phase liquid droplet removal. Separation Science And Technology, $28,5,1127-1143$.

Schima, S., D. J. Labrecque, and P. D. Lundegrad. 1996. Monitoring air sparging using resistivity tomography. Ground Water Monitoring and Remediation 16, no.2: 131-138.

Stalkup, Fred I. 1970. Displacement of oil by solvent at high water saturation. Society of Petroleum Engineers Journal, 10:337-348.

Shelton, J. L., and F. N. Schneider. 1975. The effect of water injection on miscible flooding methods using hydrocarbons and carbon dioxide. Society of Petroleum Engineers Journal, 15:217-226.

Spence, A. P., Jr. and R.W. Watkins. 1980. The effect of microscopic core hetrogeneity on miscible flood residual oil saturation. SPE 9229, presented at the $55^{\text {th }}$ Annual Fall Technical Conference and Exhibition of the Society of Petroleum Engineers, Dallas, Texas.

Wilson, D.J., S. Kayano, R. D. Mutch, and A. N. Clarke. 1992. Groundwater cleanup by in situ sparging, I, mathematical modeling. Separation Science and Technology, 27 no. 8 \& 9: 1023-1041.

Original Manuscript Received: June 6, 2001

Revised Manuscript Received: March 11, 2002 